\title{
The Reformation of the Decalogue: Religious Identity and the Ten Commandments in England, c. 1485-1625
}

Review Number: 2208

Publish date: Thursday, 14 December, 2017

Author: Jonathan Willis

ISBN: 9781108241526

Date of Publication: 2017

Price: $£ 90.00$

Publisher: Cambridge University Press

Publisher url: https://www.cambridge.org/core/books/reformation-of-thedecalogue/AC5B0CA62CDCCBEC6C9C9230FBE36D35

Place of Publication: Cambridge

Reviewer: John Reeks

'No Christian man whatsoever is free from the obedience of the commandments which are called moral'. This is the clear instruction given in the seventh of the 39 Articles, but it seems to completely contradict the message of the 11th: 'We are accounted righteous before God, only for the merit of our Lord and Saviour Jesus Christ, and not for our own works or deservings'. The Protestant God did not keep a heavenly ledger of merits and demerits: humanity could not hope to appease, satiate, or bargain with Him through their good works. Only through faith was man justified, and only from justification did the soteriological engine of regeneration, sanctification and salvation proceed. So then, why should a justified Christian - for that matter, any Christian - be expected to keep the moral law? This is one paradox of the English Reformation. The other, as Jonathan Willis explains in this rich and ever-compelling book, is that the Ten Commandments (or Decalogue, or moral law) themselves laid down an unrealistic moral code that a wretched humanity could never live up to: 'the whole point of their enumeration was to damn sinful mankind, for whom they were impossible to obey with the spiritual perfection required by God' (p. 12). With problems as complex and terrifying as these to deal with, it is small wonder that Reformed Christianity did not crumble inexorably into ranting antinomianism and libertinism. Chief among Willis's achievements is the elucidation of how it was all held together. The book has two principal arguments. First, that the Reformation 'repurposed, indeed reinvented' the Decalogue, which itself became a ubiquitous presence in early modern England. Second, that the Ten Commandments themselves helped to shape the course of the Reformation; doctrinally, magisterially, culturally, and politically (pp. 5-6). Willis is extremely persuasive on the first. It was through discourses on the moral law, which are distilled so clearly in this fine volume, that certain English clerics worked through the ideas about sin and salvation which counteracted the most anarchic readings of key Protestant tenets of faith. This problem solved, the commandments became a powerful rhetorical tool in support of magisterial authority, the social order, and pastoral care. The second argument is a little more contentious, even provocative, and I shall return to it later in this review.

This is Willis's second monograph and, like the first, it shows the author's keen eye for the historiographical lacuna. His Church Music and Protestantism in post-Reformation England (1) explored the rather unexpected extent to which music shaped the course of the English Reformation. This book takes a seemingly more obvious topic, the Ten Commandments, but is all the more remarkable for it. As he explains 
in the opening pages, it is quite baffling that this issue has not been addressed at length before, the result, one thinks he is right to note, of historians being 'unable to see the remarkable quality of the wood for the incredible quantity and apparent simplicity of the trees' (p. 5). One feature of the English Reformation, he claims, is that it was able to 'make the familiar feel new' (p. 353). In that case, Willis would have made a first-rate reforming cleric himself. This book has the feel of instant familiarity, but to probe the surface is to reveal the true depth of the author's originality. Readers will no doubt be left with the gnawing feeling that this really should have been done before. Yet it has not, and the result is a work which provides not just a thorough and learned discourse on the commandments, but which also serves as a vital guide to godly clerics and their ideas more generally. This reviewer is, strange though it may sound, reminded of Stuart Clark's work on demonology, which made the point that the 'sense' of a body of ideas may lie 'in its coherence with ideas about other things'.(2) The way that Willis's subjects juggled with the Decalogue, in order to address issues around conversion, justification, and predestination, seems not altogether dissimilar. In short, the Ten Commandments have a very real historical significance and Willis's book emphatically succeeds in putting the Decalogue firmly on the map of Reformation historiography. Since this book represents so much more than just the collective sum of its constituent parts, this review will move quite briskly through its contents, to allow greater space for consideration of its contribution as a whole.

Reformation of the Decalogue is organised in three parts, each concerning one of the three functions, or 'offices', of the moral law: the 'socio-political', the 'theological', and the 'religio-cultural'. Sections are then further subdivided into two chapters. The 'socio-political' office concerns how the commandments functioned as civil laws, and this section addresses how earthly magistrates and the Decalogue were imagined as mutually reinforcing one another. The first chapter, 'Law', establishes the broad conceptual backbone of the book as a whole. As the Ten Commandments were a direct expression of the divine will, unlike the ceremonial and judicial laws of the Old Testament, they 'remained a binding force on Christians everywhere' (p. 70). The second chapter, 'Order', which draws heavily upon Assize sermons, shows how the Decalogue was used not just as a buttress to magisterial authority, by stressing obedience, subordination, and hierarchy, but also explores the 'complex nexus of duties and responsibilities' which characterised relationships between governors and governed in a variety of contexts (pp. 104-12). The second office, the 'theological', is argued to have been evangelical in nature on the grounds that it was crucial in 'defining the evangelical doctrine of justification by faith alone'. The third chapter, 'Sin', demonstrates that, for protestant divines, the 'whole point ... was to demand the impossible', to 'hardwire sin into the human condition', to elucidate the sheer number of sins humanity was culpable of, and to demonstrate the impossibility of escaping from them (p. 140, p. 149, p. 164). This was a terrifying message for the faithful Christian dutifully trying to keep the commandments, but of course that was the whole point. The regenerate, upon realising their total depravity, would be driven towards a truer state of repentance and faith, a process dealt with in the fourth chapter, 'Salvation'. The third section, dealing with the 'socio-political' office of the Decalogue, is about the practical and applied results of the prior discussions: what were ordinary Christians, upon hearing these messages, supposed to actually $d o$ ? This section is again subdivided into two chapters, quite tellingly so, 'The godly' and 'The ungodly'. The fifth chapter, drawing upon the distinctive genre of godly lives, convincingly outlines what the author describes as a 'puritan penitential cycle': reflection on the impossible demands of the moral law would throw the godly back towards faith, making it 'the primary tool employed for the ongoing process of self-examination' (p. 233). The 'ungodly' - the vast majority of the population, who may have disagreed with this characterisation - would reject or fail to understand this message, falling back on vain attempts to please, appease, or bargain with God. In truth, this chapter is not so much about popular belief as it is about attempts to disseminate and explain the commandments, drawing as it does upon 'manifestations' of the Decalogue (physical, musical) and 'assessments of popular belief occasionally made by godly authors and other commentators' (p. 337).

Willis is to be applauded for corralling and distilling such a wealth of information, much of which can be complex, confusing, and downright inaccessible in its original form. The result is a book of magnificent authorial choreography: my instinct, to draw comparisons with the author of Willis's subject matter, will be resisted owing to the fact that it runs counter to the First Commandment. This disciplining process has, 
naturally enough, required compromises and choices, and it is through these that the book takes its distinctive shape. Three in particular can be identified. The first is historiographical and represents the broader scholarship to which Willis contributes. The second is historical and, in particular, is defined by the chronology adopted. The third concerns the type of source material drawn upon. These three choices not only give the final work a kind of polyphonic harmony marked by fluent argumentation and internal consistency, but they also make the book the product of a very particular branch of post-Reformation scholarship. This review will take each in turn.

First is the author's self-conscious decision to identify his book as belonging to the school of thought broadly known as 'post-revisionism'. Specifically, Willis argues that 'the concepts of "Anglican" and "puritan" ... have been comprehensively redrawn by forty years of evolving reformation historiography, not least the considerable oeuvres of Nicholas Tyacke and Patrick Collinson' (p. 7). Broadly speaking, the Collinson-Tyacke oeuvre may be sketched in the following terms: there were no 'Anglicans' before 1642 at the very earliest. The Church of England was doctrinally Calvinist before 1625 and 'puritanism' was effectively just mainstream Reformed Protestantism by a derogatory name. This 'Calvinist consensus' was disrupted by Archbishop William Laud and the clerics around him in the 1630s - the so-called 'rise of Arminianism' thesis.(3) The notion of the Anglican via media was thus a matter of hindsight rather than one of historical reality; a product of the redefinitions and rewritings of later generations of ecclesiastics and historians. While it would be wrong to suggest that all 'post-revisionist' scholars have accepted this thesis in absolute terms, it is fair to say that the influence has been very strong. Combined with the rise of cultural history more generally, it has prompted a major shift in emphasis, towards a growing scholarship which has sought to analyse key features of English Protestant culture rather than attempt to re-shape the basic narrative.(4) The aim of Willis's book is, broadly, to take post-revisionists' arguments forward without challenging the essentials and, specifically, to 'reintegrate ... belief and praxis' through what is called a 'cultural history of theology' (p. 10). What this means in practice is that we are shown how clerics used the Ten Commandments to elucidate key Reformed tenets such as justification and predestination, and how working within the framework of the Commandments affected the formulation and expression of those tenets in turn.

Second is the chronological framing and, in particular, the decision to end the story in 1625 . Defended on the grounds that this marks a 'convenient caesura', Willis admits that taking the study forward to consider the rest of the 17th century 'would hold much value' (p. 14). It is of course natural that any historical study must end somewhere, and it would be unreasonable to criticise the difficult but necessary decisions made in the process of managing such a large research project. It is also the case, however, that the ideas presented here significantly affect readings of the 1630s and vice versa. As noted above, working within the oeuvre of Collinson and Tyacke may ultimately demand an account of the 1630s. For instance, Willis notes that the requirement to erect commandment boards drops off the bishops' visitation articles from the 1570s, arguing that this signifies 'that most [parish churches] had acquired a board of some kind' (p. 303). The fact that such requirements returned in the 1630s, then, may indicate that compliance was less widespread than Willis suggests.(5) Of greater significance is the way that the Laudians thought with and about the Decalogue. Described by Collinson as 'the greatest calamity ever visited upon the English Church' and by Tyacke as the man who effectively outlawed Calvinism by redefining it as 'puritanism', it is quite surprising to see Laud and his allies drawing upon the Ten Commandments in a fashion which screams orthodox and mainstream Reformed Protestantism.(6) Laud's own private devotions reveal his acceptance that keeping of the commandments could only follow grace. Similarly, we find William Piers of Bath and Wells talking about shedding 'ten teares for my sinnes' and finding comfort in God as the penitent sinner who 'sorroweth for his sinnes, and rejoyceth for his repentence'. Alexander Huish, the Laudian rector of Beckington in Somerset, talked about the commandments in much the same way as an Arthur Dent or William Perkins, as 'the rule and square of our life and actions'.(7) Certainly, this proves Willis's claim that the Decalogue was a ubiquitous presence and the basis of a shared discourse, but it also raises questions about how great - and in what sense - a break with the past the 1630 s really were.

The third key feature of this work concerns the choice of sources and methodology. Aside from the final 
chapter, which draws heavily upon material culture in the form of surviving Decalogue Boards, most of the book is based upon printed tracts, ranging within that category from theological treatises to assize sermons and godly lives. The main principle governing the selection of sources is that a work should be 'talking specifically about God's law, or about an issue as it relates specifically to the Decalogue', though the reader is warned that 'decisions are based upon quite a finely-honed sense of what is relevant' and are 'ultimately arbitrary' (p. 13). It has to be wondered whether this is a fairly self-selecting methodology, in the sense that those given to extended consideration of the moral law (especially in print) also tended to be those favouring explicit exposition of Calvinist doctrines in their pastoral and ministerial roles. At times, it must be said, the discussion can seem to turn on the collective output of a godly Who's Who. For instance, the evidence for the Second Commandment inspiring a kind of 'active divinity' based upon the hearing of sermons and meditating upon them is drawn from the austere John Brinsley, the tellingly-titled 'minister of God's Word' Richard Bruch, the Marian martyr John Bradford, John Winthrop's spiritual inspiration Ezekiel Culverwell, arch-predestinarian Stephen Denison, and John Downame, a suspected nonconformist who later worked with the Westminster Assembly (pp. 45-6). As the first work of its kind, it is understandable why Willis has made the decisions that he has: the printed material offers copious evidence for the ways in which the Decalogue was 'confessionalised, polemicised, emphasised and utilised' in the century or so following the break with Rome (p. 5). This book actively invites further research, rather than present itself as the final word, and there is indeed much to be done. The present reviewer, for instance, wonders whether ballad literature might offer some important clues about the wider dissemination of the moral law, or about whether deponents in court cases shaped their stories according to precepts taken from the commandments. No doubt every reader will have ideas about how this research can be taken forward, especially when it comes to understanding how the Decalogue featured in the everyday lives of ordinary Christians, but this should be seen as a strength of the book, not a deficiency.

These three characteristics - historical/chronological, historiographical, methodological - make this book what it is: a full-throttled work of 'post-revisionism'. Those who already accept the basic post-revisionist framework will find much to agree with and, it must be admitted, that amounts to the vast majority of present scholars. Those outside the oeuvre (and the present reviewer counts himself one of their number) will feel this is a book that is largely about puritan readings of the Ten Commandments, rather than about the English Reformation more generally. This is my reason for proposing, as I did at the start of this review, that Willis's second core argument about the Decalogue itself helping to shape the course of the English Reformation is 'contentious, even provocative'. Such a reading requires acceptance of the core tenets of postrevisionism: that 'puritanism' was mainstream, that the Church of England established in law was something few really wanted, and that 'Anglicanism' was an invention of later generations. We are all in agreement that the English Reformation was hard-fought, and that the notion of an 'Anglican' via media, or middle way between Catholicism and Protestantism, was little more than a helpful rhetorical device.(8) Nevertheless, the Reformation required hard choices; compromises resulting in the generation and fossilisation of certain artefacts, whether doctrinal, liturgical, textual, or political. Perhaps these did not represent a via media so much as a set of lowest common denominators that could be read and understood in a wide variety of ways. As a bare text with no obvious or inherent meaning, the Decalogue itself seems to have been one of those artefacts. As Willis observes in the final chapter, the commandments themselves do not talk about justification and predestination, and their physical manifestations in parish churches could be presented as both 'impeccably reformed' and pastorally 'optimistic', depending upon taste (p. 314). It will therefore be difficult for 'Anglican Insiders', such as they have been labelled by Nicholas Tyacke, to accept that godly agreement about the status and meaning of the moral law shows how the 'Ten Commandments themselves helped to shape the course of the English reformation'.

That Willis should invite such a disagreement is, I think, a mark of his success. In whichever way this book's readers view the overall case presented, the wealth of information presented within it, combined with the author's incisive analysis and linguistic flair, guarantee that it will meet with approval from all quarters. This is a quite wonderful book, always thought-provoking and rooted in a wide-ranging and sharp survey of its source material. It is a wealth of insights, a source of inspiration, and a punchy provocation. The Ten 
Commandments are now, thanks to Jonathan Willis, where they should be: firmly at the centre of postReformation scholarship.

\section{Notes}

1. Jonathan Willis, Church Music and Protestantism in post-Reformation England (London, 2010).Back to $(1)$

2. Stuart Clark, Thinking with Demons: The Idea of Witchcraft in Early Modern Europe (Oxford, 1997), p. viii.Back to (2)

3. See Patrick Collinson, The Religion of Protestants: The Church in English Society, 1559-1625 (Oxford, 1982), pp. 282-3; Nicholas Tyacke, Anti-Calvinists: The Rise of English Arminianism, 1590-1640 (Oxford, 1990), pp. 6-7. As Alexandra Walsham has recently noted, it is a view 'suffused with nostalgia ... for the pre-Laudian era' and possessed of an ingrained 'distaste for William Laud': Walsham, 'The Religion of Protestants: The Church in English Society, 1559-1625', History, 100, 342 (2015), 345, 350. It is also, coincidentally, the view established and promoted by the puritan pamphleteer William Prynne, solicitor for the prosecution at the trial of William Laud by the Long Parliament, in his 1646 Canterburies Doome. Back to (3)

4. For example, Alexandra Walsham, Providence in Early Modern England (Oxford, 1999); Peter Lake with Michael Questier, The Antichrist's Lewd Hat: Protestants, Papists and Players in PostReformation England (New Haven, CT, and London, 2002); Tara Hamling, Decorating the Godly Household: Religious Art in Post-Reformation Britain (London, 2010); Alec Ryrie, Being Protestant in Reformation Britain (Oxford, 2015). Back to (4)

$<$

5. For example, Laud's 1634 metropolitan articles for Lincoln, in Visitation Articles and Injunctions of the Early Stuart Church, edited by Kenneth Fincham, 2 vols., II (Woodbridge, 1998), p. 85; William Piers's 1636 diocesan articles for Bath and Wells, STC2: 10137.9.Back to (5)

6. Patrick Collinson, The Religion of Protestants (Oxford, 1982), p. 90; Nicholas Tyacke, AntiCalvinists: The Rise of English Arminianism, 1590-1640 (Oxford, 1990), p. 181.Back to (6)

7. See Willis pp. 180-5; Huish, Lectures upon the Lords Prayer (1626), STC2: 13927, p. 8; Piers, Two Sermons Preached in the Tower (1642), Wing 2: P2211, p. 68; Works of William Laud, edited by John Henry Parker, 8 vols., III (Oxford, 1847-1860), p. 18.Back to (7)

8. Most famously, Diarmaid MacCulloch, 'The Myth of the English Reformation', Journal of British Studies, 30, 1 (1991), 1-19.Back to (8)

Source URL:https://reviews.history.ac.uk/review/2208

\section{Links}

[1] https://reviews.history.ac.uk/item/287412 